\title{
PENGARUH CORPORATE GOVERNANCE (CG) TERHADAP KUALITAS LABA DENGAN MANAJEMEN LABA SEBAGAI VARIABEL INTERVENING PADA PERUSAHAAN MANUFAKTUR YANG TERDAFTAR DI BEI PERIODE 2015-2017
}

\author{
Alvin Pranata Nanang1, Hendang Tanusdjaja² \\ ${ }^{1}$ Magister Akuntansi, Universitas Tarumanagara Jakarta \\ Email: alvinpranata@hotmail.com \\ ${ }^{2}$ Fakultas Ekonomi, Universitas Tarumanagara Jakarta \\ Email: hendangt@gmail.com
}

Masuk : 30-01-2019, revisi: 30-10-2019, diterima untuk diterbitkan : 30-10-2019

\begin{abstract}
ABSTRAK
Penelitian ini dilakukan untuk menguji bagaimana pengaruh mekanisme tata kelola perusahaan (corporate governance) dalam hal ini yaitu: kepemilikan institusional, kepemilikan manajerial, komite audit, dan dewan komisaris independen terhadap kualitas laba dengan manajemen laba sebagai variabel intervening. Data yang digunakan dalam penelitian ini ialah data sekunder yang diperoleh melalui laporan keuangan dan laporan tahunan dari masing-masing perusahaan. Laporan keuangan dan laporan tahunan tersebut diperoleh melalui www.idx.co.id. Analisis data dalam penelitian ini yaitu analisis jalur dengan SEM dengan menggunakan SMARTPLS 3. Populasi dalam penelitian ini ialah seluruh perusahaan manufaktur yang terdaftar di BEI pada periode 2015-2017, dengan total sampel sebesar 28 perusahaan. Hasil penelitian ini membuktikan bahwa mekanisme corporate governance dalam hal ini yaitu: kepemilikan institusional, kepemilikan manajerial, komite audit, dan dewan komisaris independen tidak memiliki pengaruh signifikan baik terhadap manajemen laba maupun kualitas laba. Manajemen laba berpengaruh signifikan terhadap kualitas laba. Mekanisme corporate governance dalam penelitian ini menunjukkan bahwa hanya kepemilikan institusional dan dewan komisaris independen yang memiliki pengaruh signifikan terhadap kualitas laba dengan manajemen laba sebagai variabel intervening, sedangkan kepemilikan manajerial dan komite audit tidak berpengaruh signifikan terhadap kualitas laba dengan manajemen laba sebagai variabel intervening.
\end{abstract}

Kata Kunci: Institutional Ownership, Managerial Ownership, Audit Comitees, Independent Commissioner, Earning's Quality, Earning's management.

\section{ABSTRACT}

This study was conducted to examine how the influence of corporate governance mechanisms in this case, namely: institutional ownership, managerial ownership, audit committee, and independent board of commissioners on earnings quality with earnings management as an intervening variable. The data used in this study are secondary data obtained through financial reports and annual reports from each company. The financial statements and annual reports are obtained through www.idx.co.id. Analysis of the data in this study is path analysis with SEM using SMARTPLS 3. The population in this study are all manufacturing companies listed on the Indonesia Stock Exchange in the period 2015-2017, with a total sample of 28 companies. The results of this study prove that corporate governance mechanisms in this case are: institutional ownership, managerial ownership, audit committee, and the independent board of commissioners do not have a significant effect both on earnings management and earnings quality. Earnings management has a significant effect on earnings quality. The corporate governance mechanism in this study shows that only institutional ownership and independent board of commissioners have a significant influence on earnings quality with earnings management as an intervening variable, while managerial ownership and audit committees do not significantly influence earnings quality with earnings management as an intervening variable.

Keyword : Institutional Ownership, Managerial Ownership, Audit Comitees, Independent Commissioner, Earning's Quality, Earning's management. 


\section{PENDAHULUAN}

\section{Latar belakang}

Laporan laba rugi merupakan salah satu laporan yang memberikan informasi mengenai pendapatan, beban, serta laba (earnings) yang dicapai oleh perusahaan selama periode tertentu. Laba yang berhasil dicapai oleh perusahaan akan menjadi tolak ukur kinerja dan pertimbangan bagi kreditur dan debitur dalam melakukan pengambilan keputusan untuk memberikan tambahan kredit dan berinvestasi. Perusahaan yang melaporkan laba yang tinggi dalam laporan keuangannya tentu akan membuat gembira para investor yang menanamkan modalnya dalam perusahaan karena mereka akan memperoleh dividen atas setiap kepemilikan saham yang dimilikinya sehingga mereka tidak akan ragu untuk berinvestasi dalam perusahaan tersebut. Demikian juga dengan para kreditur, mereka akan semakin merasa yakin bahwa mereka akan menerima pendapatan bunga dan pengembalian pokok pinjaman yang diberikan kepada perusahaan sehingga mereka yakin untuk memberikan tambahan kredit bagi perusahaan.

Laba yang berkualitas baik dalam laporan keuangan ialah laba yang memang mencerminkan keadaan perusahaan saat ini dan bebas dari manipulasi yang dilakukan oleh pihak manajemen sehingga laba tersebut dapat digunakan untuk pengambilan keputusan. Manipulasi tersebut dapat dilakukan oleh manajemen dengan cara, yaitu manajemen laba.

Kualitas laba dapat dipengaruhi oleh ada tidaknya manajemen laba (earning management) yang dilakukan manajemen. Hal ini terjadi disebabkan adanya perbedaan kepentingan antara prinsipal (pemilik perusahaan atau pemegang saham) dan agen (manajemen). Perbedaan kepentingan antara kedua pihak inilah yang disebut dengan agency conflict. Agency conflict ini mengakibatkan adanya sifat manajemen melaporkan laba secara oportunis untuk memaksimalkan kepentingan pribadinya (self-interested). Manajemen seharusnya bertindak untuk kemakmuran pemilik perusahaan, namun seringkali manajemen mempertimbangkan kembali keputusannya karena adanya risiko yang mungkin akan diterima perusahaan dan untuk kepentingan pribadinya. Hal inilah yang menyebabkan rendahnya kualitas laba yang ada dalam laporan keuangan.

Selain itu pada kenyataannya dalam dunia bisnis, praktik manajemen laba sering dikaitkan dengan adanya indikasi kualitas laba (earnings quality) yang diterapkan oleh perusahaan. Earnings quality diindikasikan sebagai suatu kemampuan laba dalam memberi tanggapan (respon) terhadap pasar (Wahyuni dan Muslim, 2010).

Di dalam penelitian terdahulu terdapat beberapa hasil penelitian yang tidak konsisten seperti penelitian Rona et al (2015) dan Taruno (2013) yang menyimpulkan bahwa earning management berpengaruh positif signifikan terhadap earnings quality. Sedangkan Nurgaha (2016) dan Wahyuni dan Muslim (2010) menyimpulkan bahwa manajemen laba berpengaruh signifikan negatif terhadap kualitas laba.

Untuk memaksimumkan kualitas laba yang tercermin dalam laporan keuangan dan menghindari adanya praktik earning management yang dilakukan manajemen perusahaan diperlukan suatu mekanisme tata kelola perusahaan yang baik atau sering juga disebut sebagai tata kelola perusahaan atau Corporate Governance $(C G)$.

Dengan adanya tata kelola perusahaan yang baik, akan memberikan sinyal kepada pemegang saham bahwa laba yang akan dihasilkan perusahaan baik dan berkualitas. Hal ini disebabkan oleh dengan adanya tata kelola perusahaan yang baik maka akan memotivasi dan mengontrol 
sifat manajemen dalam melakukan aktivitas operasional perusahaan. Dengan demikian, dampak yang timbul akibat adanya tata kelola perusahaan yang baik di suatu perusahaan diduga0akan mempengaruhi hubungan antara manajemen laba dengan kualitas laba. (Rifani, 2009).

Ada empat mekanisme corporate governance yang sering dipakai dalam berbagai penelitian mengenai corporate governance yang bertujuan untuk mengurangi konflik keagenan, yaitu kepemilikan institusional, kepemilikan manajerial, komite audit dan komisaris independen. Dengan adanya empat mekanisme ini diharapkan dapat mengurangi kegiatan manajemen laba yang dilakukan oleh manajemen dan berdampak pada meningkatnya kualitas laba perusahaan.

Kepemilikan institusional merupakan seberapa besar persentase saham yang dimiliki oleh institusi atau lembaga seperti perusahaan asuransi, investasi, dan lainnya baik lokal maupun asing terhadap saham perusahaan. Di dalam penelitian terdahulu terdapat beberapa hasil penelitian yang tidak konsisten seperti penelitian Astari dan Suryawana (2017) yang menyimpulkan adanya pengaruh yang signifikan antara kepemilikan institusional dengan manajemen laba dan kualitas laba. Sedangkan Murtini dan Mansyur (2012) menyimpulkan bahwa kepemilikan institusional tidak berpengaruh signifikan terhadap earnings management dan penelitian Irawati dan Sudirman (2016) menyimpulkan bahwa kepemilikan institusional tidak berpengaruh signifikan terhadap earnings quality.

Kepemilikan manajerial adalah seberapa besar persentase saham-saham yang dipunyai oleh manajemen perusahaan terhadap saham perusahaan. Di dalam penelitian terdahulu terdapat beberapa hasil penelitian yang tidak konsisten seperti penelitian Rona et al (2015) yang menyimpulkan adanya pengaruh yang tidak signifikan diantara kepemilikan manajerial terhadap earnings management dan adanya pengaruh yang signifikan diantara kepemilikan manajerial dengan earnings quality. Sedangkan Murtini dan Mansyur (2012) menyimpulkan bahwa kepemilikan manajerial berdampak signifikan terhadap manajemen laba dan penelitian Irawati dan Sudirman (2016) menyimpulkan bahwa kepemilikan manajerial tidak berdampak terhadap earnings quality.

Komite audit yang efektif diperlukan dalam pencapaian corporate governance. Komite audit diperlukan untuk melakukan pengawasan dan kontrol terhadap manajemen sehingga dapat meminimalkan tindakan manajemen laba yang dilakukan manejemen dan meningkatkan kualitas laba dalam laporan keuangan (Sari dan Putri, 2014). Di dalam penelitian terdahulu terdapat beberapa hasil penelitian yang tidak konsisten seperti penelitian Rona et al (2015) yang menyimpulkan adanya pengaruh yang signifikan antara komite audit dengan manajemen laba dan kualitas laba. Sedangkan Nabila dan Daljono (2013) menyimpulkan bahwa komite audit tidak berpengaruh signifikan terhadap manajemen laba dan penelitian Rilo dan Laksito (2017) menyimpulkan bahwa ukuran komite audit tidak berpengaruh signifikan terhadap kualitas laba.

Dewan komisaris independen menurut Fama dan Jensen (dalam Murtini dan Mansyur, 2016) mengatakan bahwa kehadiran non-executive director dapat berperilaku sebagai mediator dalam konflik-konflik yang sedang terjadi diantara para manajer-manajer internal dan bertugas mengawasi kebijakan-kebijakan yang diambil oleh manajemen dan juga memberikan nasihat dan masukan untuk manajemen. Di dalam penelitian terdahulu terdapat beberapa hasil penelitian yang tidak konsisten seperti penelitian Eva dan Khoiruddin (2016) yang menyimpulkan bahwa proporsi dewan komisaris independen berpengaruh signifikan terhadap manajemen laba dan penelitian Rona et al (2015) yang menyatakan bahwa dewan komisaris berdampak signifikan 
pada kualitas laba. Sedangkan Taruno (2013) menyimpulkan bahwa proporsi komisaris independen tidak berpengaruh signifikan terhadap manajemen laba dan penelitian Farida dan Kusumumaningtyas (2017) menyimpulkan bahwa komisaris independen tidak berpengaruh signifikan terhadap kualitas laba.

\section{Rumusan Masalah}

Berdasarkan latar belakang yang telah diuraikan di atas, dapat dirumuskan beberapa masalahmasalah yang akan dibahas yaitu :

1. Apakah corporate governance dalam hal ini yaitu kepemilikan institusional, kepemilikan manajerial, komite audit, dan dewan komisaris independen berpengaruh terhadap kualitas laba?

2. Apakah corporate governance dalam hal ini yaitu kepemilikan institusional, kepemilikan manajerial, komite audit, dan dewan komisaris independen berpengaruh terhadap manajemen laba?

3. Apakah manajemen laba berpengaruh terhadap kualitas laba?

4. Apakah corporate governance dalam hal ini kepemilikan institusional, kepemilikan manajerial, komite audit, dan dewan komisaris independen berpengaruh terhadap kualitas laba dengan manajemen laba sebagai variabel intervening?

\section{Kerangka Pemikiran dan Hipotesis}

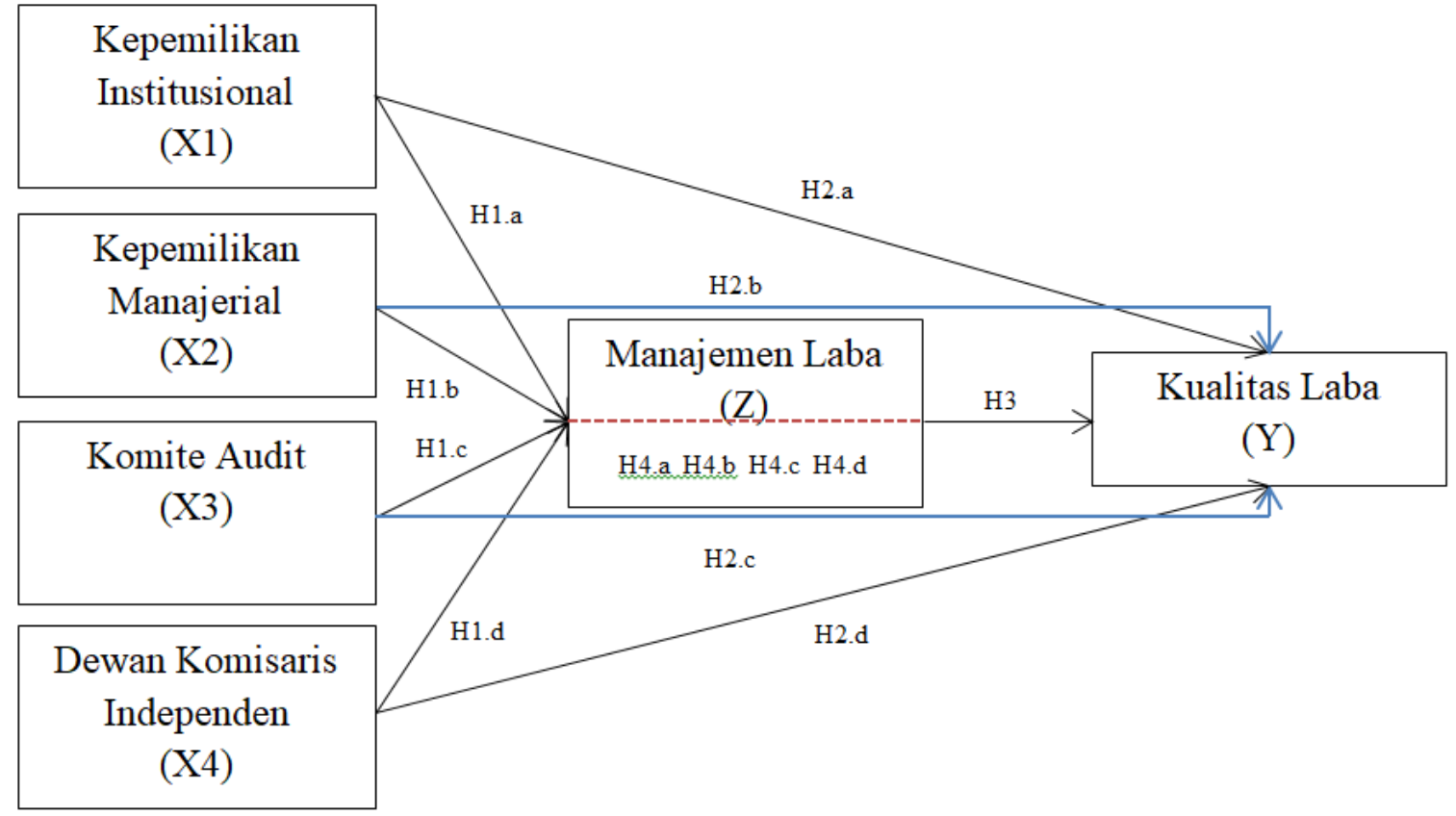

Gambar 1. Kerangka Pemikiran

Sumber: Hasil Olahan Penulis (2018)

\section{H1.a : Pengaruh Kepemilikan Institusional terhadap Manajemen Laba}

Kepemilikan institusional mempunyai kemampuan untuk mengendalikan manajemen melalui monitoring sehingga mampu mengurangi praktik manajemen laba. Konsentrasi kepemilikan saham tertentu yang dimiliki oleh institusi-institusi dapat mempengaruhi proses saat penyusunan laporan keuangan yang tidak menutup kemungkinan juga terdapat akrualisasi sesuai dengan 
kepentingan pihak manajemen (Boediono : 2005). Oleh karena itu, dapat diprediksi bahwa kepemilikan institusional berpengaruh negatif dengan manajemen laba.

\section{H1.b : Pengaruh Kepemilikan Manajerial terhadap Manajemen Laba}

Semakin besar tingkat kepemilikan saham oleh manajemen maka akan semakin mengurangi praktik manajemen laba yang terjadi di perusahaan. Hal ini dikarenakan manajemen yang sekaligus pemegang saham memiliki motivasi yang sama dengan pemegang saham perusahaan yaitu meningkatkan nilai perusahaan sehingga praktik manajemen laba akan minim dilakukan. Penelitian Murtini dan Mansyur (2012) menunjukkan hasil bahwa kepemilikan manajerial memiliki pengaruh negatif terhadap manajemen laba. Dengan demikian, diprediksi bahwa kepemilikan manajerial memiliki hubungan negatif terhadap manajemen laba.

\section{H1.c : Pengaruh Komite Audit terhadap Manajemen Laba}

Irawati dan Sudirman (2016) menyatakan bahwa komite audit berperan efektif dalam meningkatkan keandalan laporan keuangan dan memberi bantuan pada dewan komisaris mendapatkan kepercayaan dari investor untuk memenuhi kewajiban dalam penyampaian informasi. Penelitian Rona et al (2015) menunjukkan hasil bahwa komite audit berpengaruh negatif terhadap manajemen laba. Dengan demikian, diprediksi bahwa komite audit memiliki hubungan negatif terhadap manajemen laba.

\section{H1.d : Pengaruh Dewan Komisaris Independen terhadap Manajemen Laba}

Komisaris independen merupakan posisi terbaik untuk melaksanakan fungsi monitor agar tercipta perusahaan dengan tata kelola yang baik. Penelitian Pranata dan Mas'ud (2003) menyatakan bahwa perusahaan yang memiliki proporsi anggota dewan komisaris yang berasal dari luar perusahaan dapat mempengaruhi tindakan manajemen laba. Dengan demikian, diprediksi bahwa dewan komisaris independen memiliki pengaruh negatif terhadap manajemen laba.

\section{H2.a : Pengaruh Kepemilikan Institusional terhadap Kualitas Laba}

Irawati dan Sudirman (2016) mengatakan bahwa kepemilikan institusional bertindak sebagai pihak yang melaksanakan fungsi monitoring perusahaan pada umumnya dan manajemen sebagai pengelola perusahaan pada spesifiknya. Hasil penelitian Rona et al (2015) menunjukkan bahwa kepemilikan institusional berpengaruh negatif terhadap kualitas laba. Dengan demikian, diprediksi bahwa kepemilikan institusional memiliki pengaruh terhadap kualitas laba.

\section{H2.b : Pengaruh Kepemilikan Manajerial terhadap Kualitas Laba}

Jensen dan Mecking (dalam Irawati dan Sudirman, 2016) mengatakan semakin tinggi kepemilikan saham oleh manajemen, maka akan semakin meningkat kecenderungan manajemen untuk mengoptimalkan penggunaan sumber daya. Kepemilikan manajemen terhadap saham perusahaan di pandang dapat menyelaraskan potensi perbedaan kepentingan atara pemegang saham luar dan manajemen sehingga agency conflict akan berkurang apabila seorang manajer adalah sekaligus pemegang saham. Hasil penelitian Rona et al (2015) menunjukkan bahwa kepemilikan manajerial berpengaruh positif terhadap kualitas laba. Dengan demikian, diprediksi bahwa kepemilikan manajerial memiliki hubungan positif terhadap kualitas laba.

\section{H2.c : Pengaruh Komite Audit terhadap Kualitas Laba}

Dengan adanya komite audit dalam suatu perusahaan dapat melakukan pengawasan dan monitoring terhadap kinerja manajemen apakah sudah sesuai dengan standar dan tujuan yang 
ditetapkan perusahaan. Semakin besar ukuran komite audit yang ada dalam perusahaan dalam batas yang optimum maka semakin besar kualitas laba yang tercermin dalam laporan keuangan. Hasil penelitian Rona et al (2015) menunjukkan bahwa komite audit berpengaruh positif terhadap kualitas laba. Dengan demikian, diprediksi bahwa komite audit memiliki hubungan positif terhadap kualitas laba.

\section{H2.d : Pengaruh Dewan Komisaris Independen terhadap Kualitas Laba}

Boediono (2005) menyatakan bahwa struktur dewan komisaris dapat menjadi salah satu alat mekanisme corporate governance yang dapat menggambarkan kekuatan dari kualitas laba. Sedangkan dari pola hubungannya komposisi komisaris terhadap kualitas laba dapat diketahui adalah positif yang artinya semakin banyak dewan komisaris independen yang ada di perusahaan maka akan semakin tinggi kualitas laba dalam laporan keuangan. Dengan demikian, diprediksi bahwa dewan komisaris independen memiliki hubungan positif terhadap kualitas laba.

\section{H3 : Pengaruh Manajemen Laba terhadap Kualitas Laba}

Wahyuni dan Muslim (2010) dalam penelitiannya menyatakan bahwa praktik manajemen laba mengakibatkan penurunan kualitas dari laba yang akan dilaporkan. Laba dapat dikatakan berkualitas tinggi jika laba yang dilaporkan tersebut dapat digunakan oleh pengguna laporan keuangan untuk membuat keputusan yang terbaik bagi kelangsungan hidup perusahaan. Dengan demikian, diprediksi bahwa manajemen laba memiliki pengaruh terhadap kualitas laba.

\section{H4.a : Pengaruh Kepemilikan Institusional terhadap Kualitas laba yang Dimediasi oleh Manajemen Laba}

Besarnya konsentrasi kepemilikan saham yang dimiliki oleh suatu institusi dalam suatu perusahaan akan menurunkan praktik manajemen laba yang dilakukan oleh manajemen. Dengan rendahnya praktik manajemen laba dalam suatu perusahaan akan meningkatkan kualitas dari laba yang dilaporkan. Hasil penelitian Rona et al (2015) menunjukkan bahwa kepemilikan institusional terbukti memiliki pengaruh terhadap kualitas laba dengan manajemen laba sebagai variabel intervening. Dengan demikian dapat disimpulkan bahwa manajemen laba memediasi pengaruh antara kepemilikan institusional terhadap kualitas laba.

\section{H4.b : Pengaruh Kepemilikan Manajerial terhadap Kualitas laba yang Dimediasi oleh Manajemen Laba}

Manajemen yang sekaligus pemegang saham dalam suatu perusahaan akan mengoptimalkan penggunaan sumber daya yang ada di dalam perusahaan untuk mencapai tujuan jangka panjang perusahaan. Hal ini akan membuat manajemen menghindari praktik manajemen laba guna memperoleh laba dengan kualitas baik atau laba yang sebenarnya. Hasil penelitian Rona et al (2015) menunjukkan bahwa kepemilikan manajerial tidak terbukti berpengaruh terhadap kualitas laba melalui manajemen laba sebagai variabel intervening. Dengan demikian dapat disimpulkan bahwa manajemen laba memediasi pengaruh antara kepemilikan manajerial terhadap kualitas laba.

\section{H4.c : Pengaruh Komite Audit terhadap Kualitas laba yang Dimediasi oleh Manajemen} Laba

Rupilu (2011) menyatakan bahwa dengan adanya komite audit dalam perusahaan yang mempunyai kinerja yang profesional akan mampu mengidentifikasi ada tidaknya tindakan manajemen laba lebih dini, sehingga sebagai salah satu mekanisme pengendali dalam penyusunan laporan laba akan memberikan pengaruh terhadap peningkatan kualitas laba. Hasil 
penelitian Rona et al (2015) menunjukkan bahwa komite audit terbukti berpengaruh terhadap kualitas laba melalui manajemen laba sebagai variabel intervening. Dengan demikian dapat disimpulkan bahwa manajemen laba memediasi pengaruh antara komite audit terhadap kualitas laba.

\section{H4.d : Pengaruh Dewan Komisaris Independen terhadap Kualitas laba yang Dimediasi oleh Manajemen Laba}

Komposisi dewan komisaris yang ada di perusahaan dapat mempengaruhi kualitas laba yang dilaporkan. Perusahaan dengan komposisi anggota dewan komisaris yang berasal dari luar perusahaan mampu mempengaruhi praktik manajemen laba yang dilakukan oleh manajemen. Hasil penelitian Rona et al (2015) menunjukkan bahwa dewan komisaris terbukti mempengaruhi kualitas laba melalui manajemen laba sebagai variabel intervening. Dengan demikian dapat disimpulkan bahwa manajemen laba memediasi pengaruh antara dewan komisaris independen terhadap kualitas laba.

\section{METODE PENELITIAN Desain Penelitian}

Penelitian ini menggunakan desain penelitian konklusif kausal untuk menguji pengaruh variabelvariabel independen corporate governance (X) terhadap kualitas laba (Y) sebagai variabel terikat (dependent variable) dan manajemen Laba $(\mathrm{Z})$ sebagai variabel mediasinya (intervening variable).

Data yang digunakan dalam penelitian ini adalah data kuantitatif, yaitu data yang diukur dalam suatu skala numerik (angka). Penelitian ini menggunakan data sekunder yaitu data yang telah dikumpulkan oleh pihak lain dan dipublikasikan kepada masyarakat pengguna data. Data yang digunakan berupa laporan keuangan tahunan yang telah diaudit dan dapat memberikan informasi mengenai kepemilikan institusional, kepemilikan manajerial, komite audit, dan dewan komisaris independen, manajemen laba, dan kualitas laba.

\section{Populasi dan Teknik Pemilihan Sampel}

Populasi dalam penelitian ini ialah seluruh perusahaan manufaktur yang terdaftar dalam Bursa Efek Indonesia periode tahun 2015-2017. Teknik pemilihan sampel dalam penelitian ini menggunakan non probability sampling dengan metode purposive sampling. Metode purposive sampling yaitu pemilihan sampel berdasarkan kriteria-kriteria yang telah ditetapkan. Kriteriakriteria pemilihan sampel yang digunakan di dalam penelitian ini ialah: (a) Perusahaanperusahaan manufaktur yang terdaftar di Bursa Efek Indonesia (BEI) secara berturut-turut periode tahun 2015-2017, (b) Perusahaan-perusahaan yang menyajikan laporan keuangan dalam mata uang Rupiah, (c) Perusahaan-perusahaan yang mengalami laba berturut-turut selama periode 2015-2017, dan (d) Perusahaan-perusahaan yang menyajikan laporan keuangan yang diaudit yang berakhir saat 31 Desember pada periode 2015-2017, (d) Perusahaan yang menyajikan informasi-informasi yang dibutuhkan dalam penelitian.

\section{Operasionalisasi Variabel \\ Kualitas Laba}

$$
\text { Quality of Income Ratio }=\frac{\text { Cash Flow from Operation }}{\text { Net income }}
$$




\title{
Manajemen Laba
}

Manajemen laba dapat diukur dengan cara menghitung discretionary accrual sebagai proxy dari manajemen laba yang dihitung dengan menggunakan Modified Jones Model. Model perhitungannya sebagai berikut :

$\mathrm{TA}_{\mathrm{it}}=\mathrm{N}_{\mathrm{it}}-\mathrm{CFO}_{\mathrm{it}}$

Nilai Total Accrual (TA) yang diestimasi dengan persamaan regresi OLS sebagai berikut:

$\mathrm{TA}_{\mathrm{it}} / \mathrm{A}_{\mathrm{it}-1}=\beta_{1}\left(1 / \mathrm{A}_{\mathrm{it}-1}\right)+\beta_{2}\left(\Delta \mathrm{REV}_{\mathrm{t}} / \mathrm{A}_{\mathrm{it}-1}\right)+\beta_{3}\left(\mathrm{PPE} / \mathrm{A}_{\mathrm{it}-1}\right)+\varepsilon$.

Dengan menggunakan koefisien regresi diatas, nilai Non Discretionary Accruals (NDA) dapat dihitung dengan rumus sebagai berikut:

$\mathrm{NDA}_{i t}=\beta_{1}\left(1 / \mathrm{A}_{\mathrm{it}-1}\right)+\beta_{2}\left(\Delta \mathrm{REV}_{\mathrm{t}} / \mathrm{A}_{\mathrm{it}-1}-\Delta \mathrm{REC}_{\mathrm{t}} / \mathrm{A}_{\mathrm{it}-1}\right)+\beta_{3}\left(\mathrm{PPE}_{\mathrm{t}} / \mathrm{A}_{\mathrm{it}-1}\right)$.

Selanjutnya Discretionary Accrual (DA) dapat dihitung sebagai berikut :

$\mathrm{DA}_{\mathrm{it}}=\mathrm{TA}_{\mathrm{it}} / \mathrm{A}_{\mathrm{it}-1}-\mathrm{NDA}_{\mathrm{it}}$

Dimana:

DA $_{\text {it }}$ : Discretionary accruals perusahaan $i$ pada periode $t$

$\mathrm{NDA}_{\text {it }}$ : Non discretionary accruals perusahaan $i$ pada periode $t$

$\mathrm{TA}_{\text {it }}$ : Total akrual perusahaan $i$ pada periode $t$

$\mathrm{N}_{\mathrm{it}}$ : Laba bersih perusahaan $i$ pada periode $t$

$\mathrm{CFO}_{\text {it }}$ : Aliran kas dari aktivitas operasi perusahaan $i$ pada periode $t$

$\mathrm{A}_{\mathrm{it}-1}$ : Total aktiva perusahaan $i$ pada periode $t$

$\triangle \mathrm{REV}_{\mathrm{t}}$ : Perubahan penjualan perusahaan $i$ dari tahun $t-1$ ke tahun $t$

PPE : Aktiva tetap perusahaan pada periode $t$

$\Delta \mathrm{REC}_{\mathrm{t}}$ : Perubahan piutang perusahaan $i$ dari tahun $t-1$ ke tahun $t$

$\varepsilon:$ error

\section{Kepemilikan Institusional}

$$
\text { Kepemilikan Institusional }=\frac{\text { Jumlah Saham yang dimiliki Institusi }}{\text { Jumlah Saham Beredar }}
$$

\section{Kepemilikan Manajerial}

$$
\text { Kepemilikan Manajerial }=\frac{\text { Jumlah Saham yang dimiliki Manajemen }}{\text { Jumlah Saham Beredar }}
$$

Komite Audit

$$
\text { Komite Audit }=\frac{\text { Jumlah Komite Audit }}{\text { Jumlah Komisaris }}
$$

\section{Dewan Komisaris Independen}

Dewan Komisaris Independen $=\frac{\text { Jumlah Komisaris Independen }}{\text { Jumlah Komisaris }}$

\begin{abstract}
Analisis Data
Teknik pengolahan data terdiri dari beberapa tahap, yaitu statistik deskriptif untuk melihat gambaran analisis, uji outer model untuk melihat hubungan antara indikator terhadap variabel konstruknya, uji inner model untuk menggambarkan hubungan dan pengaruh antar variabel, dan uji hipotesis untuk menguji apakah hipotesis penelitian ditolak atau tidak ditolak. Semua data diolah dengan menggunakan sebuah program, yaitu program SPSS versi 23.0 dan SmartPLS 3
\end{abstract}




\section{HASIL DAN PEMBAHASAN}

\section{Obyek Penelitian}

Berikut adalah tabel tahap seleksi sampel dalam penelitian ini :

Tabel 1. Seleksi Sampel

Sumber: Hasil Olahan Penulis (2018)

\begin{tabular}{|c|c|}
\hline Keterangan & Jumlah Perusahaan \\
\hline $\begin{array}{c}\text { Perusahaan manufaktur yang terdaftar di BEI } \\
\text { secara berturut-turut pada periode 2015-2017 }\end{array}$ & $(26)$ \\
\hline $\begin{array}{c}\text { Perusahaan manufaktur yang tidak } \\
\text { menggunakan mata uang rupiah dalam } \\
\text { laporan keuangannya pada periode 2015-2017 }\end{array}$ & $(32)$ \\
\hline $\begin{array}{c}\text { Perusahaan manufaktur yang tidak mengalami } \\
\text { laba berturut-turut selama periode 2015-2017 }\end{array}$ & $(29)$ \\
\hline $\begin{array}{c}\text { Perusahaan manufaktur yang tidak lengkap } \\
\text { menyajikan laporan keuangan yang telah } \\
\text { diaudit pada periode 2015-2017 }\end{array}$ & $(5)$ \\
\hline $\begin{array}{c}\text { Perusahaan manufaktur yang baru melakukan } \\
\text { IPO pada periode 2015-2017 }\end{array}$ & $(2)$ \\
\hline $\begin{array}{c}\text { Perusahaan manufaktur yang baru delisting } \\
\text { pada periode 2015-2017 }\end{array}$ & $(33)$ \\
\hline $\begin{array}{c}\text { Perusahaan manufaktur yang tidak memiliki } \\
\text { informasi-informasi yang dibutuhkan pada } \\
\text { periode 2015-2017 }\end{array}$ & $\mathbf{2 8}$ \\
\hline $\begin{array}{c}\text { Jumlah perusahaan sampel setelah } \\
\text { diseleksi }\end{array}$ & $\mathbf{3}$ \\
\hline Tahun pengamatan (tahun) & $\mathbf{8 4}$ \\
\hline Jumlah data pengamatan total pada & \\
\hline
\end{tabular}

Dari tabel di atas bisa dilihat bahwa terdapat data perusahaan manufaktur awal sebanyak 155 perusahaan yang kemudian diseleksi dengan kriteria-kriteria yang telah ditentukan sehingga didapat jumlah data akhir perusahaan yang akan digunakan dalam penelitian ini sebanyak 28 perusahaan per tahunnya dengan 3 tahun pengamatan sehingga jumlah data dalam penelitian ini sebanyak 84 data.

\section{Statistik Deskriptif}

Tabel 2. Statistik Deskriptif

Sumber : Pengolahan Data SPSS 23.0

\begin{tabular}{|l|r|r|r|r|r|}
\hline Variable & \multicolumn{1}{|c|}{ N } & \multicolumn{1}{c|}{ Minimum } & \multicolumn{1}{c|}{ Maximum } & \multicolumn{1}{c|}{ Mean } & \multicolumn{1}{c|}{ Std. Deviation } \\
\hline KEP_INST & 84 & 0,02112 & 0,97784 & 0,54597 & 0,29122 \\
\hline KEP_MNGR & 84 & 0,00000 & 0,41252 & 0,08334 & 0,11699 \\
\hline KOM_AUD & 84 & 0,30769 & 1,50000 & 0,84685 & 0,29989 \\
\hline KOM_IND & 84 & 0,28571 & 0,60000 & 0,39619 & 0,07948 \\
\hline ML & 84 & $-0,17930$ & 0,22701 & $-0,01815$ & 0,06044 \\
\hline KL & 84 & $-4,21235$ & 57,93606 & 2,86497 & 8,82948 \\
\hline Valid N (listwise) & 84 & & & & \\
\hline
\end{tabular}

Tabel di atas menunjukkan statistik deskriptif dari variabel-variabel yang digunakan dalam penelitian ini. Tabel ini ditujukan untuk memberikan gambaran atau deskriptif suatu data yang 
dilihat dari nilai rata-rata (mean), nilai minimum, nilai maksimum, standar deviasi, dan jumlah data digunakan dalam penelitian ini.

\section{Hasil Uji Asumsi}

Dalam analisis data mengenai pengaruh Corporate Governance $(C G)$ terhadap kualitas laba dengan manajemen laba sebagai variabel intervening diperoleh model path diagram (diagram jalur) sebagai berikut :

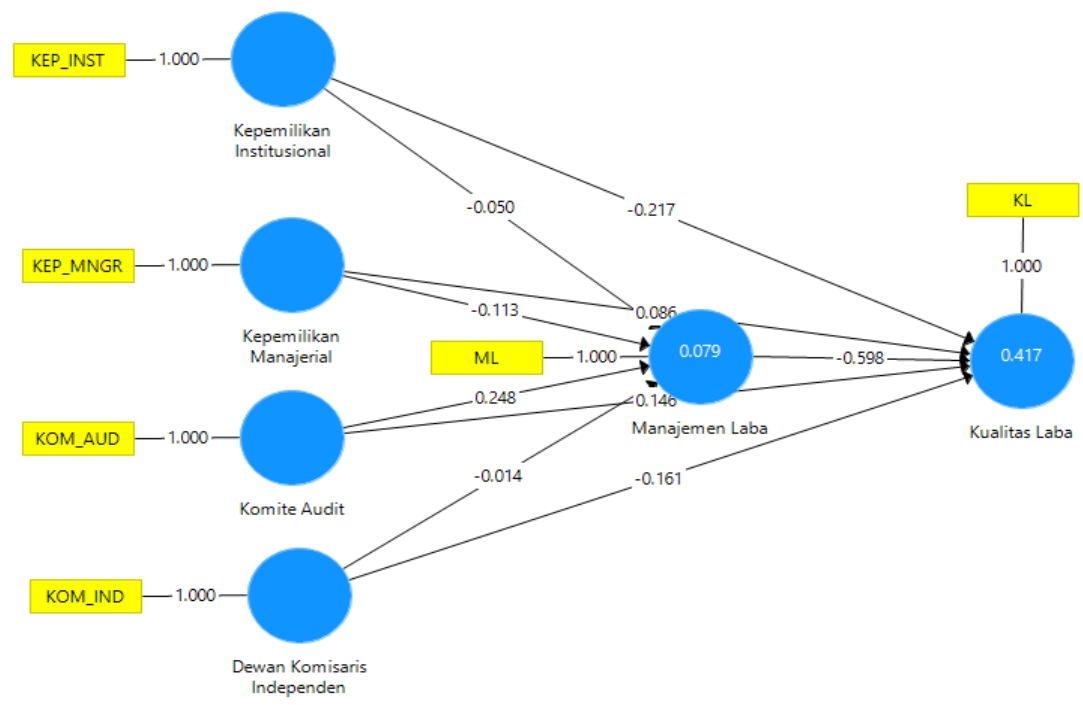

Gambar 2. Diagram Jalur

Sumber : Pengolahan Data SmartPLS 3

\section{Uji Outer Model}

\section{Convergent Validity}

Nilai convergent validity yang diharapkan harus lebih besar dari 0.5. Dari Gambar 2 di atas dapat dilihat bahwa semua indikator berada di atas kriteria yaitu sebesar 1.000. Selain dinilai dari nilai loading factornya, convergent validity juga dinilai dari angka Average Variance Extracted $(A V E)$. Nilai $A V E$ yang diharapkan adalah lebih besar dari 0.5. Berikut merupakan tabel nilai Average Variance Extracted (AVE) dalam penelitian ini :

Tabel 3. Average Variance Extracted (AVE)

Sumber : Pengolahan Data SmartPLS 3

\section{Average Variance Extracted (AVE)}

\begin{tabular}{|c|c|c|}
\hline \multirow[t]{2}{*}{ 模 Average Variance Extracted ( } & Matrix & \\
\hline & \multicolumn{2}{|c|}{ Average Variance Extracted (AVE) } \\
\hline Dewan Komisaris Independen & & 1.000 \\
\hline Kepemilikan Institusional & & 1.000 \\
\hline Kepemilikan Manajerial & & 1.000 \\
\hline Komite Audit & & 1.000 \\
\hline Kualitas Laba & & 1.000 \\
\hline Manajemen Laba & & 1.000 \\
\hline
\end{tabular}


Dalam penelitian ini nilai dari AVE masing-masing variabel lebih besar dari 0,5. Oleh karena itu tidak terdapat permasalahan convergent validity pada model penelitian yang diuji.

\section{Discriminant Validity}

Discriminant validity adalah pengukuran indikator variabel laten. Nilai pada konstruk yang dituju harus lebih tinggi daripada angka loading factor terhadap konstruk lainnya. Discriminant validity dapat di uji dengan melihat nilai dari tabel cross loading. Berikut merupakan tabel nilai cross loading dalam penelitian ini :

Tabel 4. Discriminant Validity

Sumber : Pengolahan Data SmartPLS 3

\section{Discriminant Validity}

\begin{tabular}{|c|c|c|c|c|c|c|c|c|c|}
\hline \multicolumn{2}{|c|}{ Fornell-Larcker Criterion } & \multirow{2}{*}{$\begin{array}{l}\text { Cross Loadings } \\
\text { Komisaris Independen }\end{array}$} & \multicolumn{2}{|c|}{ Heterotrait-Monotrait Ratio (HTMT) } & \multicolumn{3}{|c|}{ 旿 } & \multirow{2}{*}{\multicolumn{2}{|c|}{$\begin{array}{r}\text { Export to clif } \\
\text { Manajemen Laba }\end{array}$}} \\
\hline & Dewan Komisaris Independen & & Kepemilikan Institusional & \multicolumn{2}{|c|}{ Kepemilikan Manajerial } & Komite Audit & & & \\
\hline KEP_INST & & 0.007 & 1.000 & & -0.248 & 0.190 & & -0.227 & 0.025 \\
\hline KEP_MNGR & & 0.191 & -0.248 & & 1.000 & -0.179 & & 0.171 & -0.148 \\
\hline $\mathrm{KL}$ & & -0.125 & -0.227 & & 0.171 & -0.097 & & 1.000 & -0.581 \\
\hline KOM_AUD & & 0.210 & 0.190 & & -0.179 & 1.000 & & -0.097 & 0.256 \\
\hline KOM_IND & & 1.000 & 0.007 & & 0.191 & 0.210 & & -0.125 & 0.017 \\
\hline ML & & 0.017 & 0.025 & & -0.148 & 0.256 & & -0.581 & 1.000 \\
\hline
\end{tabular}

Dari tabel penelitian di atas dapat dilihat bahwa angka loading masing-masing variabel terhadap konstruknya lebih tinggi daripada angka loading (nilai loading pada variabel laten lain). Dari hasil analisa cross loading terlihat bahwa tidak ada permasalahan discriminant validitynya sehingga variabel dapat dikatakan valid.

\section{Unidimensionality}

Uji unidimensionalitas dilakukan dengan memakai indikator composite reliability dan cronbach's alpha. Berikut merupakan tabel nilai composite reliability dan cronbach's alpha dalam penelitian ini :

Tabel 5. Composite Reliability dan Cronbach's Alpha

Sumber : Pengolahan Data SmartPLS 3

\begin{tabular}{|l|c|lc|} 
& Composite Reliability & & Cronbach's Alpha \\
\hline Dewan Komisaris Independen & 1.000 & Dewan Komisaris Independen & 1.000 \\
\hline Kepemilikan Institusional & 1.000 & Kepemilikan Institusional & 1.000 \\
\hline Kepemilikan Manajerial & 1.000 & Kepemilikan Manajerial & 1.000 \\
Komite Audit & 1.000 & Komite Audit & 1.000 \\
\hline Kualitas Laba & 1.000 & Kualitas Laba & 1.000 \\
\hline Manajemen Laba & 1.000 & Manajemen Laba & 1.000
\end{tabular}

Dari tabel di atas dapat dilihat bahwa nilai dari indikator composite reliability sebesar 1.0000 yang berarti lebih besar dari nilai batas yang dapat diterima yaitu 0.70 dan nilai dari indikator cronbach's alpha sebesar 1.0000 yang berarti juga lebih tinggi dari nilai batas yang dapat diterima yaitu 0.60 , yang menunjukkan bahwa semua variabel-variabel di atas sudah memenuhi syarat sehingga tidak perlu adanya modifikasi model. 


\section{Uji Inner Model \\ R-square}

Uji $R$-square digunakan untuk mengetahui seberapa besar presentase sumbangan variabel eksogen yaitu Corporate Governance (CG) dalam hal ini kepemilikan institusional, kepemilikan manajerial, komite audit, dan dewan komisaris independen mampu untuk memprediksi variabel dependen yaitu kualitas laba dan variabel intervening yaitu manajemen laba secara bersamasama. Berikut merupakan tabel nilai $R$-square dalam penelitian ini :

Tabel 6. R-square

Sumber : Pengolahan Data SmartPLS 3

\begin{tabular}{cc} 
& R Square \\
\hline Kualitas Laba & 0.417 \\
\hline Manajemen Laba & 0.079
\end{tabular}

Dari tabel di atas dapat dilihat hasil perhitungan nilai $R$-square yang diperoleh pada perusahaan manufaktur yang terdaftar di Bursa Efek Indonesia pada periode 2015-2017 adalah sebesar 0.417 atau $41.7 \%$ untuk variabel kualitas laba dan sebesar 0.079 atau $7.9 \%$ untuk variabel manajemen laba. Hal ini menunjukkan bahwa presentase sumbangan variabel independen yaitu Corporate Governance $(C G)$ dalam menjelaskan variabel dependen yaitu kualitas laba adalah sebesar 0.417 atau $41.7 \%$ dan sisanya sebesar 0.583 atau $58.3 \%$ dipengaruhi faktor-faktor di luar model penelitian ini dan Corporate Governance $(C G)$ dalam menjelaskan variabel intervening yaitu manajemen laba adalah sebesar 0.079 atau $7.9 \%$ dan sisanya sebesar 0.921 atau $92.1 \%$ dipengaruhi oleh faktor-faktor lain di luar model ini.

\section{Q-square Predictive Relevance}

Penilaian goodness of fit pada model ini dapat diketahui dari nilai $Q$-square. $Q$-square juga dapat mengukur seberapa baik nilai observasi yang dihasilkan oleh model dan juga estimasi parameternya. Jika $Q$-square $>0$ berarti menunjukkan bahwa model memiliki predictive relevance, sebaliknya jika nilai $Q$-square $<0$ menunjukkan model kurang memiliki predictive relevance (Ghozali, 2011). Perhitungan $Q$-square dapat dilakukan dengan rumus :

$$
Q^{2}=1-\left(1-R_{1}^{2}\right)\left(1-R_{2}^{2}\right) \ldots\left(1-R_{p}^{2}\right)
$$

Berdasarkan rumus di atas dapat diperoleh nilai $Q$-square yaitu :

$$
\begin{aligned}
& Q^{2}=1-(1-0.417)(1-0.079) \\
& Q^{2}=0.4631 \\
& Q^{2}=46.31 \%
\end{aligned}
$$

Dari hasil perhitungan nilai $Q$-square sebesar $46.31 \%$ yang artinya besar keragaman dari data penelitian yang dapat dijelaskan model struktural adalah sebesar $46.31 \%$, sedangkan sebesar $53.69 \%$ sisanya dijelaskan oleh variabel-variabel lain diluar model dan model ini memiliki nilai predictive relevance yang baik dan memiliki kapabilitas prediksi yang kuat sehingga uji hipotesis dapat dilakukan.

\section{Hasil Uji Hipotesis}

Uji hipotesis ini dilakukan dengan melihat nilai statistik t atau $p$ value suatu variabel independen terhadap dependennya. Jika hasil uji statistik t menunjukkan nilai $p$ values $<0.05$ maka Ho ditolak dan Ha diterima. Artinya terdapat pengaruh antara variabel independen terhadap variabel 
dependen. Jika hasil uji statistik t menunjukkan nilai $p$ values $\geq 0.05$ maka Ho diterima dan Ha ditolak. Artinya tidak terdapat pengaruh antara variabel independen terhadap variabel dependen. Berikut merupakan tabel yang memperlihatkan hasil uji statistik $t$ dalam penelitian ini :

Tabel 7. Total Effects

Sumber : Pengolahan Data SmartPLS 3

Total Effects

\begin{tabular}{|c|c|c|c|c|c|c|c|}
\hline \multirow[t]{2}{*}{ 圂 Mean, STDEV, T-Values, P-Values } & Confidence Intervals & \multicolumn{2}{|c|}{ Confidence Intervals Bias Corrected } & \multirow{2}{*}{$\begin{array}{l}\text { Samples } \\
\text { Standard Dev }\end{array}$} & \multicolumn{3}{|c|}{ Export to clipboard: } \\
\hline & Origina & al Sample (O) & Sample Mean (M) & & (STDEV) & T Statistics $(|\mathrm{O} / \mathrm{STDEV}|)$ & P Values \\
\hline \multicolumn{2}{|c|}{ Dewan Komisaris Independen -> Kualitas Laba } & -0.152 & -0.161 & & 0.118 & 1.292 & 0.197 \\
\hline \multicolumn{2}{|c|}{ Dewan Komisaris Independen $->$ Manajemen Laba } & -0.014 & 0.020 & & 0.147 & 0.093 & 0.926 \\
\hline \multicolumn{2}{|c|}{ Kepemilikan Institusional -> Kualitas Laba } & -0.187 & -0.189 & & 0.102 & 1.829 & 0.068 \\
\hline \multicolumn{2}{|c|}{ Kepemilikan Institusional -> Manajemen Laba } & -0.050 & -0.035 & & 0.126 & 0.395 & 0.693 \\
\hline \multicolumn{2}{|c|}{ Kepemilikan Manajerial -> Kualitas Laba } & 0.153 & 0.148 & & 0.107 & 1.440 & 0.150 \\
\hline \multicolumn{2}{|c|}{ Kepemilikan Manajerial -> Manajemen Laba } & -0.113 & -0.113 & & 0.120 & 0.943 & 0.346 \\
\hline \multicolumn{2}{|l|}{ Komite Audit -> Kualitas Laba } & -0.002 & 0.000 & & 0.084 & 0.025 & 0.980 \\
\hline \multicolumn{2}{|l|}{ Komite Audit -> Manajemen Laba } & 0.248 & 0.212 & & 0.225 & 1.105 & 0.270 \\
\hline \multicolumn{2}{|l|}{ Manajemen Laba -> Kualitas Laba } & -0.598 & -0.608 & & 0.095 & 6.306 & 0.000 \\
\hline
\end{tabular}

Untuk melihat apakah variabel manajemen laba mampu memediasi hubungan antara variabel Corporate Governance terhadap variabel kualitas laba, dapat dilakukan dengan cara mengkalikan loading factor masing-masing variabel independen tersebut terhadap manajemen laba dan loading factor manajemen laba terhadap kualitas laba sehingga diperoleh nilai indirect effect. Kemudian hasilnya dibandingkan dengan hasil loading factor hubungan secara langsung (direct effect) antara masing-masing variabel independen tersebut terhadap kualitas laba. Jika nilai perkalian itu lebih besar artinya variabel manajemen laba mampu memediasi hubungan antara variabel Corporate Governance terhadap variabel kualitas laba. Berikut merupakan tabel nilai pengaruh langsung (direct effects) dan pengaruh tidak langsung (indirect effects) dalam penelitian ini :

Tabel 8. Direct Effects dan Indirect Effects

Sumber : Hasil Olahan Penulis (2018)

\begin{tabular}{|c|c|c|}
\hline Pengaruh & Direct Effects & Indirect Effects \\
\hline Kepemilikan Institusional $\rightarrow$ Kualitas Laba & -0.217 & \\
\hline Kepemilikan Institusional $\rightarrow$ Manajemen Laba & -0.05 & $-0.05 \times-0.598=$ \\
\hline $\begin{array}{c}\text { Kepemilikan Institusional } \rightarrow \text { Manajemen } \\
\text { Laba } \rightarrow \text { Kualitas Laba }\end{array}$ & & 0.030 \\
\hline Kepemilikan Manajerial $\rightarrow$ Kualitas Laba & 0.086 & \\
\hline Kepemilikan Manajerial $\rightarrow$ Manajemen Laba & -0.113 & $-0.113 \times-0.598=$ \\
\hline $\begin{array}{c}\text { Kepemilikan Manajerial } \rightarrow \text { Manajemen } \\
\text { Laba } \rightarrow \text { Kualitas Laba }\end{array}$ & & 0.068 \\
\hline Komite Audit $\rightarrow$ Kualitas Laba & 0.146 & $0.248 \times-0.598=-$ \\
Komite Audit $\rightarrow$ Manajemen Laba & 0.248 & 0.148 \\
\hline $\begin{array}{c}\text { Komite Audit } \rightarrow \text { Manajemen Laba } \rightarrow \text { Kualitas } \\
\text { Laba }\end{array}$ & & \\
\hline Dewan Komisaris Independen $\rightarrow$ Kualitas Laba & -0.161 & -0.014 \\
\hline $\begin{array}{c}\text { Dewan Komisaris Independen } \rightarrow \text { Manajemen } \\
\text { Laba }\end{array}$ & & 0.068 \\
\hline $\begin{array}{c}\text { Dewan Komisaris Independen } \rightarrow \text { Manajemen } \\
\text { Laba } \rightarrow \text { Kualitas Laba }\end{array}$ & & $-0.598=$ \\
\hline Manajemen Laba $\rightarrow$ Kualitas Laba & -0.598 & \\
\hline
\end{tabular}

Berikut merupakan ringkasan dari hasil pengujian hipotesis yang telah dilakukan dalam penelitian ini : 
Tabel 9. Ringkasan Hasil Pengujian Hipotesis

Sumber : Hasil Olahan Penulis (2018)

\begin{tabular}{|c|c|c|}
\hline No & Hipotesis & Hasil \\
\hline 1 & $\begin{array}{c}\text { Kepemilikan institusional berpengaruh terhadap } \\
\text { manajemen laba }\end{array}$ & H1.a ditolak \\
\hline 2 & $\begin{array}{c}\text { Kepemilikan manajerial berpengaruh terhadap } \\
\text { manajemen laba }\end{array}$ & H1.b ditolak \\
\hline 3 & Komite audit berpengaruh terhadap manajemen laba & H1.c ditolak \\
\hline 4 & $\begin{array}{c}\text { Dewan komisaris independen berpengaruh terhadap } \\
\text { manajemen laba }\end{array}$ & H1.d ditolak \\
\hline 5 & $\begin{array}{c}\text { Kepemilikan institusional berpengaruh terhadap kualitas } \\
\text { laba }\end{array}$ & H2.a ditolak \\
\hline 6 & $\begin{array}{c}\text { Kepemilikan manajerial berpengaruh terhadap kualitas } \\
\text { laba }\end{array}$ & H2.b ditolak \\
\hline 7 & Komite audit berpengaruh terhadap kualitas laba \\
\hline 8 & $\begin{array}{c}\text { Dewan komisaris independennberpengaruh terhadap } \\
\text { kualitasslaba }\end{array}$ & H2.c ditolak \\
\hline 9 & Manajemen laba berpengaruh terhadap kualitas laba & H3 diterima \\
\hline 10 & $\begin{array}{c}\text { Kepemilikaniinstitusional berpengaruh tidak langsung } \\
\text { terhadap kualitas laba dengan manajemen labassebagai } \\
\text { variabel intervening }\end{array}$ & H4.a diterima \\
\hline 11 & $\begin{array}{c}\text { Kepemilikan manajerial berpengaruh tidak langsung } \\
\text { terhadap kualitasslaba dengan manajemen laba sebagai } \\
\text { variabel intervening }\end{array}$ & H4.b ditolak \\
\hline 12 & $\begin{array}{c}\text { Komite audit berpengaruh tidak langsung terhadap } \\
\text { kualitas laba dengan manajemen laba sebagai variabel } \\
\text { intervening }\end{array}$ & H4.c ditolak \\
\hline $\begin{array}{c}\text { Dewannkomisaris independennberpengaruh tidak } \\
\text { langsung terhadapabaliabl intervening }\end{array}$ & H4.d diterima \\
\hline
\end{tabular}

\section{Pengaruh Kepemilikan Institusional terhadap Manajemen Laba}

Hasil0pengujian hipotesis (H1.a) menunjukkan bahwa variabel Corporate Governance dalam hal ini kepemilikan institusional tidak memiliki pengaruh yang signifikan terhadap manajemen laba. Proporsi kepemilikan saham yang tinggi ini seharusnya dapat membuat investor institusional mempunyai kekuatan yang lebih dalam melakukan kontrol terhadap kegiatan operasi perusahaan. Tetapi pada praktiknya, kepemilikan institusional tidak mampu membatasi terjadinyaapraktik manajemen laba. Hal ini disebabkan karenaiinvestor institusionalltidak berperan sebagai menjadi sophisticated investors yang memiliki kemampuan dan peluang yang banyak dalam memonitor dan mengatur manajer supaya lebih terfokus pada firm value, serta membatasi keputusan manajemen dalam melakukan praktik manipulasi laba, melainkan berperan sebagai transient investors yang lebih berfokus pada labaajangka pendek (current earnings) (Yang et al, 2009). Pemilik sementara justru akan membuat pihak manajer mengambil suatu kebijakan agar dapat mencapai target jangka pendek yang diinginkan para investor. Oleh karena itu, denganaadanya kepemilikan institusional yang tinggi belum tentu akan berpengaruh pada peningkatan proses kontrol yang berdampak pada berkurangnya praktik manajemen dalam melakukan manipulasi laba (Chew dan Gillan, 2009). Hal yang serupa juga diungkapkan oleh Cornett et al (2006) yang menyatakan bahwa kepemilikan institusional dapat membuat manajer merasa terikat untuk memenuhi target laba para investor-investornya, sehingga manajer tersebut akan cenderung tetap terlibat di dalam praktik manipulasi laba. 


\section{Pengaruh Kepemilikan Manajerial terhadap Manajemen Laba}

Hasil pengujian hipotesis (H1.b) menunjukkan bahwa variabel Corporate Governance dalam hal ini kepemilikan manajerial tidak berpengaruh signifikan terhadap manajemen laba. Hal tersebut mengindikasikan bahwa kepemilikan manajerialttidak dapat menjadi mekanisme aturan corporate governance yang dapat meminimalisir ketidaksesuaian kepentingan antara pihak manajemen dengan pemilik perusahaan maupun shareholders.

Dari Tabel 2. Statistik Deskriptif dapat terlihat bahwa kepemilikan manajeriallperusahaan di Indonesia cukup rendah dengan rata-rata (mean) di bawah 10\%. Hal ini membuat para manajermanajer yang memiliki saham perusahaanntersebut cenderung akan mengambil kebijakan untuk mengatur laba sesuai dengan keinginan investor (shareholders), contohnya ialah dengan menaikkan laba yang dilaporkan di laporan keuangan sehingga banyak calon shareholders yang berminat untuk menginvestasikan modal dan dapat meningkatkan harga dari saham perusahaan. Ketidaksanggupan manajemen yang juga adalah pemegang saham dalam perusahaan dalam menaikkan kualitas dari proses penyusunan laporan keuangan disebabkan oleh karena persentase manajer yang memiliki saham perusahaan cenderung sangat kecil jika disandingkan pada keseluruhan saham yang dimiliki investor-investor umum (Agustia, 2013).

\section{Pengaruh Komite Audit terhadap Manajemen Laba}

Hasil pengujian hipotesis (H1.c) menunjukkan bahwa variabel Corporate Governance dalam hal ini komite audit tidak berpengaruh signifikan terhadap manajemen laba. Dalam peraturan di Indonesia, terdapat peraturan-peraturan BAPEPAM yang mandatory yang membuat perusahaan-perusahaan membentuk suatu komite audit yang terdiri dari minimal dua orang anggota dan rata-rata perusahaan dalam penelitian ini memiliki anggota komite audit sebanyak dua orang dengan tujuan utamanya ialah hanya untuk memenuhi standar peraturan tersebut sehingga terhindarkan dari sanksi hukuman. Hal ini menyebabkan kinerja komite audit kurang optimal dan efektif dalam melakukan dan menerapkan pengawasan untuk membatasi praktik manipulasi laba (Agustia, 2013). Keberadaan suatu komiteaaudit dalam suatu perusahaan terbuka sampai saat ini masih hanya sekedar untuk memenuhi persyaratan dari pihak regulator.

\section{Pengaruh Dewan Komisaris Independen0terhadap Manajemen0Laba}

Hasil pengujian dari hipotesis (H1.d) memperlihatkan bahwa variabel Corporate Governance dalam hal ini dewan komisarisiindependen tidak memiliki pengaruh signifikantterhadap manajemen laba. Hal ini dapat dijelaskan bahwa seberapa besar proporsi dewan komisaris independen bukanlah menjadi suatu faktor utama dari keefektivitas kontrol terhadap manajemen. Akan tetapi efektivitas mekanisme pengendalian itu bergantunggpada norma, nilai-nilai, dan kepercayaan yang dianut dalam organisasi tersebut serta peran dari dewan komisaris dalam aktivitas monitoring terhadap manajemennya (Jennings,22005). Menurut Effendi (2009), dalam keterkaitannya dengan pelaksanaan good corporateegovernance di suatu perusahaan, diharapkan bahwa keberadaan komisaris termasuk komisaris independen (external) tidak hanya sebagai complement, dikarenakan dalam diri komisaris itu sendiri melekat tanggung-jawab secaraahukum. Tetapi dalam kenyataannya di Indonesia, terdapat suatu kecenderungan bahwa posisi direksi sangatlah kuat, bahkan ada direksi-direksi yang enggan membagikan wewenang serta tidak ingin memberikan informasi yang cukup kepada dewan komisaris independen. Selain itu, juga terdapat permasalahan yang cukup menghambat kinerja dari dewan komisaris independen itu sendiri yaitu masih lemahnya kapabilitas, integritas, dan kompetensi mereka. Hal tersebut terjadi karena pemilihan komisaris biasanya didasarkan pada penghargaan, hubungan keluarga, atau relasi lainnya, padahal integritas, independensi, dan kapabilitas mereka 
merupakan hal fundamental supaya penerapan good corporate governancedi dalam perusahaan dapat tercipta efektif.

\section{Pengaruh Kepemilikan Institusional terhadap Kualitas Laba}

Hasil pengujian hipotesis (H2.a) menunjukkan bahwa variabel Corporate Governance dalam hal ini kepemilikan institusional tidak berpengaruh signifikan terhadap kualitas laba. Pada dasarnya kepemilikan institusional dapat memaksa manajemen untuk meningkatkan kinerja perusahaan dengan meningkatkan laba yang berasal dari kegiatan operasi perusahaan. Tetapi, dalam penelitian ini menunjukkan bahwa kepemilikan institusional tidak berpengaruh terhadap kualitas laba yang artinya investor institusional tidak berorientasi pada laba sekarang (current earnings). Investor institusional lebih mementingkan kinerja perusahaan jangka panjang sehingga kepemilikan saham oleh institusi dapat menjadi kendala bagi perilaku opportunistik manajer (Irawati dan Sudirman, 2016). Selain itu, manajer cenderung melakukan praktik manipulasi laba dengan tujuan memenuhi target keuntungan dari pemegangssaham institusi. Manajemen terusmenerus melakukan praktik manajemen laba guna memenuhi kepentingan pemegang saham institusi yang cukup besar di perusahaan (Ujiyantho dan Pramuka, 2007). Hal ini menyebabkan kualitas laba menjadi turun dan tidak dapat menggambarkan keadaan laba yang sebenarnya atau laba yang memang benar berasal dari kegiatan operasi perusahaan.

\section{Pengaruh Kepemilikan Manajerial terhadap Kualitas Laba}

Hasil pengujian hipotesis (H2.b) menunjukkan bahwa variabel Corporate Governance dalam hal ini kepemilikan manajerial tidak berpengaruh signifikan terhadap kualitas laba. Hasil penelitian ini memberikan bukti empiris bahwa kepemilikan manajerial tidak mampu menaikkan kualitas laba perusahaan atau tidak berpengaruh terhadap kualitas laba perusahaan. Berdasarkan data dalam penelitian ini, jumlah kepemilikan manajerial pada perusahaan manufaktur yang terdaftar di Bursa Efek Indonesia periode 2015-2017 sangatlah sedikit. Banyak perusahaan-perusahaan yang tidak memiliki kepemilikan manajerial. Jumlah perusahaan yang tidak memiliki kepemilikan manajerial dalam perusahaan ini sebesar 29 perusahaan. Berdasarkan Tabel 2. Statistik Deskriptif dalam penelitian ini, rata-rata kepemilikan manajerial di bawah $10 \%$. Selain itu, berpatokan pada data-data dalam penelitian ini, beberapa struktur kepemilikan manajerial di suatu perusahaan memiliki hubungan keluarga (relasi) dan memiliki jabatan yang tinggi dan strategis dalam strukturoorganisasi perusahaan. Hal ini malahan dapat menjadi peluang terjadinya tindakan manajemen laba guna meningkatkan laba perusahaan yang menyebabkan kualitas laba tidak mencerminkan keadaan yang sebenarnya.

\section{Pengaruh Komite Audit terhadap Kualitas Laba}

Hasil pengujian hipotesis (H2.c) menunjukkan bahwa variabel Corporate Governance dalam hal ini komite audit tidak berpengaruh signifikan terhadap kualitas laba. Jumlah anggota komite audit ditentukan sesuai dengan kebutuhan perusahaan, tidak terlalu banyak ataupun sedikit (harus optimal). Adanya kesesuaian antara jumlah anggota komite audit dengan kebutuhan perusahaan akan membuat komite komite audit dapat bekerja secara lebih efisien dan efektif. Hasil ini juga didukung oleh penelitian Hamdan et al. (2013) yang tidak menemukan adanya pengaruh ukuran komite audit terhadap perbaikan kualitas laba. Adapun penambahan yang tidak cocok/sesuai dalam ukuran komite audit dapat mengarah pada sebuah pengurangan keefektifan dan keefesienan aktivitas komite audit dan juga dapat membuang biaya dan menimbulkan kekacauan dalam pekerjaan (Al-Farah dalam Hamdan et al, 2013). 


\section{Pengaruh Dewan Komisaris Independen terhadap Kualitas Laba}

Hasil pengujian hipotesis (H2.d) menunjukkan bahwa variabel Corporate Governance dalam hal ini dewan komisaris independen tidak berpengaruh signifikan terhadap kualitas laba. Jika dilihat dari Tabel 2. Statistik Deskriptif nilai rata-rata dewan komisaris independen pada perusahaanperusahaan manufaktur yang terdaftar pada Bursa Efek Indonesia periode 2015-2017 sangatlah kecil yaitu sebesar $39.62 \%$. Hal ini menunjukkan bahwa pengawasan operasional perusahaan oleh komisaris independen sangatlah minim yang disebabkan karena sedikitnya proporsi dewan komisaris independen dalam perusahaan. Kurangnya pengawasan inilah yang dapat menyebabkan terjadinya kecurangan-kecurangan dalam perusahaan yang mengakibatkan laba perusahaan menurun dan tidak sesuai keadaan yang sebenarnya. Selain itu, pengangkatan dewan komisaris biasanya juga didasarkan pada hubungan dekat dan hubungan keluarga (relasi), padahal integritas, kapabilitas, dan independensi seorang komisaris independen merupakan hal yang mendasar agar kualitas laba perusahaan dapat terjaga (Effendi, 2009).

\section{Pengaruh Manajemen Laba terhadap Kualitas Laba}

Hasil pengujian hipotesis (H3) menunjukkan bahwa variabel manajemen laba berpengaruh signifikan negatif terhadap kualitas laba. Hasil pengujian ini relevan dengan hasil pengujian yang dilakukan oleh Nugraha (2016) dan Wahyuni dan Muslim (2010). Nilai manajemen laba (discretionary accruals) yang kecil menunjukkan bahwa kualitas laba yang dihasilkan oleh perusahaan adalah besar. Sesuai dengan penjelasan sebelumnya, laba yang berkualitas tinggi adalah nilai laba yang tidak mengandung adanya manipulasi oleh pihak manajemen sehingga informasi yang terkandung dalam laba yang disajikan dalam laporan keuangan tersebut tidak menyesatkan para pengguna, serta dapat digunakan sebagai dasar pengambilan keputusan yang tepat (Wahyuni dan Muslim, 2010).

Indikasi manajemen laba dalam suatu perusahaan semakin memperkuat pandangan bahwa dalam hal pelaporan laba operasional perusahaan terdapat suatu tindakan manipulasi laba yang tercermin dalam praktik manajemen laba yang dilakukan. Laba perusahaan sangat dipengaruhi oleh semua teknik manajemen laba melalui komponen accrual. Adanya praktik manajemen laba menyebabkan penurunan kualitas dari laba yang akan dilaporkan. Laba perusahaan dikatakan berkualitas tinggi jika laba yang dilaporkan tersebut sesuai dengan laba operasional perusahaan sehingga dapat digunakan oleh pengguna laporan keuangan untuk mengambil keputusan yang terbaik bagi kelangsungan hidup perusahaan (Pudjiastuti dan Mardiyah, 2006).

\section{Pengaruh Kepemilikan Institusional terhadap Kualitas Laba dengan Manajemen Laba sebagai Variabel Intervening}

Hasil pengujian hipotesis (H4.a) menunjukkan bahwa variabel manajemen laba mampu memediasi hubungan antara Corporate Governance dalam hal ini kepemilikan institusional dengan kualitas laba. Dengan rendahnya praktik manajemen laba yang terjadi di perusahaan akan membuat hubungan antara kepemilikan institusional dengan kualitas laba semakin baik atau semakin kuat. Hal ini dikarenakan dengan adanya institusi sebagai pemegang saham melakukan pengawasan terhadap investasinya dalam perusahaan sehingga praktik manajemen laba dapat dibatasi dan membuat kualitas laba yang tercermin dalam laporan laba rugi mencerminkan keadaan yang sebenarnya. 


\section{Pengaruh Kepemilikan Manajerial terhadap Kualitas Laba dengan Manajemen Laba sebagai Variabel Intervening}

Hasil pengujian hipotesis (H4.b) menunjukkan bahwa variabel manajemen laba tidak mampu memediasi hubungan antara Corporate Governance dalam hal ini kepemilikan manajerial dengan kualitas laba. Hasil penelitian ini memberikan kesimpulan bahwa kepemilikan institusional tidak berpengaruh baik secara langsung maupun tidak langsung melalui manajemen laba terhadap kualitas laba. Meskipun manajemen laba dapat memberikan pengaruh terhadap kualitas laba secara signifikan namun manajemen laba tidak dapat membuktikan keberadaannya sebagai variabel intervening antara kepemilikan institusional terhadap kualitas laba atau tidak mampu memperkuat hubungan antara kepemilikan institusional terhadap kualitas laba.

\section{Pengaruh Komite Audit terhadap Kualitas Laba dengan Manajemen Laba sebagai Variabel Intervening}

Hasil pengujian dari hipotesis (H4.c) memperlihatkan bahwa variabel manajemen labattidak mampu memediasi hubungan antara Corporate Governance dalam hal ini komite audit dengan kualitas laba. Hal ini dikarenakan keberadaan komite audit dalam perusahaan hanya sebatas memenuhi peraturan yang ada dan anggota komite audit yang dipilih tidak memiliki kapabilitas untuk menjalankan tugasnya sehingga komite audit tidak mampu memberikan pengaruh baik kepada manajemen laba maupun kualitas laba.

Hasil penelitian ini memberikan kesimpulan bahwa komite audit tidak berpengaruh baik secara langsung maupun tidak langsung melalui manajemen laba terhadap kualitas laba. Meskipun manajemen laba dapat memberikan pengaruh terhadap kualitas laba secara signifikan namun manajemen laba tidak dapat membuktikan keberadaannya sebagai variabel intervening antara komite audit terhadap kualitas laba atau tidak mampu memperkuat hubungan antara komite audit terhadap kualitas laba.

\section{Pengaruh Dewan Komisaris0Independen terhadap Kualitas Laba dengan Manajemen Laba sebagai VariabeliIntervening}

Hasil pengujian hipotesis (H4.d) menunjukkan bahwa variabel manajemen laba mampu memediasi hubungan antara Corporate Governance dalam hal ini dewan komisaris independen dengan kualitas laba. Dengan rendahnya praktik manajemen laba yang terjadi di perusahaan akan membuat hubungan dewan komisarisiindependen dan kualitas laba semakin baik atau semakin kuat. Hal ini dikarenakan dengan adanya dewan komisarisiindependen di susunan dewan komisaris perusahaan memiliki tugas dan tanggung jawab untuk memastikan bahwapperusahaan memiliki strategi dan tujuan bisnis yang efektif, mematuhi peraturan hukum dan perundangundangan yang berlaku, serta menjamin dan meyakinkan bahwa prinsip-prinsip dari good corporate governance telah dilaksanakan dengan sebaik-baiknya (Sulistyanto, 2008). Oleh karena itu tindakan manajemen laba dapat dibatasi dan membuat kualitas laba yang tercermin dalam income statement mencerminkan keadaan yang sebenarnya.

\section{KESIMPULAN DAN SARAN}

\section{Kesimpulan}

Berdasarkan hasil penelitian yang telah dipaparkan di atas, penulis dapat menarik kesimpulan atas hasil tersebut dan dirinci dalam beberapa poin dibawah ini :

1. Berdasakan hasil uji hipotesis dengan menggunakan nilai $p$ value dari tabel total effects dan tabel direct effects and indirect effects yang didapatkan dari hasil olah data menunjukkan 
bahwa variabel-variabel corporate governance tidak berpengaruh signifikan baik terhadap manajemen laba maupun kualitas laba.

2. Berdasakan hasil uji hipotesis dengan menggunakan nilai $p$ value dari tabel total effects effects yang didapatkan dari hasil olah data menunjukkan bahwa manajemen laba berpengaruh signifikan terhadap kualitas laba.

3. Berdasakan hasil uji hipotesis dengan menggunakan nilai dari tabel direct effects and indirect effects yang didapatkan dari hasil olah data menunjukkan bahwa manajemen laba mampu membuat hubungan antara variabel corporate governance (kepemilikan institusional dan dewan komisaris independen) dengan kualitas laba lebih baik.

\section{Saran}

\section{Saran untuk Praktisi}

Saran untuk praktisi ialah dapat menggunakan hasil penelitian ini untuk menciptakan suatu mekanisme baru yang dapat mengurangi dan menghindari praktik dari manajemen laba yang dilakukan olehmmanajemen karena mekanisme corporate governance yang ada sudah tidak relevan dan tidak dapat mengurangi praktik manajemen laba dalam perusahaan. Praktik manajemen laba menjadi hal yang penting bagi praktisi karena dapat mempengaruhi kualitas laba yang sebenarnya dari perusahaan.

\section{Saran untuk Pengembang Ilmu}

Saran untuk pengembang ilmu ialah dapat menggunakan hasil penelitian ini sebagai alat untuk mengembangkan pengetahuan mengenai corporate governance, manajemen laba, dan kualitas laba. Penelitian ini juga mampu membagikan suatu pengalaman bagi para pengembang ilmu dalam mengumpulkan data dan menguji tingkat efektifitas corporate governance, manajemen laba, dan kualitas laba.

\section{Saran untuk Penelitian Selanjutnya}

Saran untuk penelitian selanjutnya ialah :

1. Penelitian selanjutnya dapat menggunakan periode waktu yang lebih panjang dan menggunakan sampel perusahaan selain perusahaan manufaktur seperti perusahaanperusahaan yang masuk dalam kategori saham blue chips.

2. Penelitian selanjutnya dapat mempertimbangkan penggunaan variabel kepemilikan institusional dan kepemilikan manajerial karena masih sedikit perusahaan manufaktur yang terdaftar di BEI periode 2015-2017 yang memiliki data tersebut sehingga sampel yang digunakan dalam penelitian selanjutnya dapat lebih banyak.

3. Penelitian selanjutnya selain hanya menggunakan jumlah proporsi dari anggota komite audit dan dewan komisaris independen dapat juga mempertimbangkan latar belakang pendidikan (kapabilitasnya) anggota komite audit dan dewan komisaris independen tersebut, jumlah kehadiran dalam RUPS, serta jumlah pertemuan dengan Board of Directors.

4. Pengukuran Quality of Income sebagai indikator untuk mengukur variabel kualitas laba dapat menggunakan pengukuran lain seperti Earning Response Coefficients (ERC)

5. Penelitian selanjutnya dapat menambahkan variabel-variabel lain yang juga mempengaruhi kualitas laba seperti : struktur modal, profitabilitas, dan leverage.

\section{REFERENSI}

Agoes dan Ardana. (2009). Etika Bisnis dan Profesi: Tantangan Membangun Manusia Seutuhnya. Edisi Revisi. Jakarta : Salemba Empat. 
Agustia, Dian (2013). Pengaruh Faktor Good Corporate Governance, Free Cash Flow, dan Leverage terhadap Manajemen Laba. Jurnal Akuntansi dan Keuangan, Vol. 15, No. 1, Mei 2013, 27-42

Al-Farah, A. (2001). The Effectiveness of Audit Committees in The Jordanian Public Shareholding Companies: Empirical Study. University of Jordan, unpublished Master dissertation

Alkdai and Hanefah (2012). Audit Committee Characteristics and Earnings Management in Malaysian Shariah-compliant Companies. Business and Management Review, 2(2), 5261

Astari dan Suryanawa. (2017). Faktor-faktorryang Mempengaruhii Manajemen Laba. E-Jurnal Akuntansii Universitass Udayana Vol.20.1. Juli (2017), pp. 290-319

Chew dan Gillan (2009). US Corporate Governance. Columbia: Columbia University Press.

Cornett et al (2006). Earnings Management, Corporate Governance, and True Financial Performance. http://papers.ssrn.com.

Dechow, P M. (1995). Detecting Manajemen laba. The Accounting Review 70, pp. 193-215.

Effendi, Arief.(2009). The Powerrof Goodd Corporate Governance Teoriidan Implementasi. Jakarta: Salemba Empat.

Eva dan Khoiruddin (2016). Pengaruh Good Corporate Governance terhadap Manajemen Laba pada Perusahaan yang Masuk Dalam JII (Jakarta Islamic Index) Tahun 2012-2013. Management Analysis Journal 5 (3).

Farida dan Kusumumaningtyas. (2017). Pengaruh Dewan KomisarissIndependen dan Kepemilikan Manajerial terhadap KualitassLaba. Jurnal STIE Semarang Vol. 9, No. 1, pp. 50-71.

Febiani, Siska (2012). KonservatismeeAkuntansi, Corporate Governance, dan KualitassLaba. Jurnal Ilmiah Mahasiswa Akuntansi, 1(2).

Fidyati, Nisa (2001). Pengaruh Mekanisme Corporate Governance terhadap Earnings Management pada Perusahaan Seasoned Equity Offering (SEO).Kompetensi, 2(1), 1-23.

Forum for Corporate Governance in Indonesia. (2002). The Essense of Good Corporate Governance. Jakarta: YPPMI Institute.

Gumanti, Tatang Ary. (2000). Earnings Management: Suatu Telaah Pustaka. Jurnal Akuntansi \& Keuangan, Vol. 2, No. 2, pp. 104-115.

Guna dan Herawaty (2010). Pengaruh Mekanisme Good Corporate Governance, Independensi Auditor, Kualitas Audit dan Faktor Lainnya terhadap Manajemen Laba. Jurnal Bisnis dan Akuntansi. 12(1): 53-68.

Hamdan et al. (2013). The Audit Committee Characteristics and Earnings Quality: Evidence from Jordan. Australasian Accounting, Business and Finance Journal, Vol. 7 No. 4.

Harahap. (2008). Analisis Kritis atas Laporan Keuangan. Jakarta : Grafindo.

Hardiningsih. et al. (2012). Determinasi Kebijakan Hutang. Dinamika Akuntansi, Keuangan dan Perbankan. Vol. 1, No. 1. ISSN :1979-4878, pp. 11 - 24.

Herianto (2013). Pengaruh Good Corporate Governance Terhadap Kualitas Laba Perusahaan Manufaktur yang Terdaftar di Bursa Efek Indonesia. Skripsi. Fakultas Ekonomi dan Bisnis Universitas Hasanudin.

Hery. (2015). Analisis Kinerja Manajemen. Jakarta : Grasindo.

Hussein, A. S. (2015). Penelitian Bisnis dan Manajemen Menggunakan Partial Least Swuares (PLS) dengan SMARTPLS 3.0. Universitas Brawijaya.

Irawati dan Sudirman. (2016). Pengaruh Good Corporate Governance terhadap Kualitas Laba pada Perusahaan Food and Beverages yang Listing di Bursa Efek Indonesia Periode 2013-2015. 
Jennings (2005). Conspicuouss Governance Failures: Why Sarbanes-Oxley Is not an Ethics Warranty. Corporate Finance Review, 9(5), 41-47.

Kasmir. (2008). Analisis Laporan Keuangan. Edisi Pertama. Jakarta : Rajawali Pers.

Kirschenheiter, M dan Melumad, N D. (2002). Can "Big Bath" and Earnings Smoothing CoExist as Equilibrium Financial Reporting Strategies?. Journal of Accounting Research Vol. 40, No. 3, pp. 761-79.

Murtini dan Mansyur. (2012). Pengaruh Corporate Governance terhadap Manajemen Laba Perusahaan di Indonesia. JRAK, Vol.8, No.1, pp. 69-78.

Murhadi, Werner R. (2009). Studi Pengaruh Good Corporate Governance terhadap Praktik Earnings Management pada Perusahaan Terdaftar di PT. Bursa Efek Indonesia. Jurnal Manajemen Dan Kewirausahaan, 11(1), 1-10.

Nabila, Afifa dan Daljono. (2013). Pengaruh ProporsiiDewan Komisaris Independen, Komite Audit dannReputasi Auditor terhadap Manajemen Laba. Jurnal Akuntansi, Vol. 2, No.1, pp. 1-10 Semarang: Fakultas Ekonomi

Natalia dan Pudjolaksono. (2013). Pengarruh Mekanisme Good Corporate Governance terhadap Praktik Earning Management Badan Usaha Sektor Perbankan di Bei 2008-2011. Calyptra: Jurnal Ilmiah Mahasiswa Universitas Surabaya Vol.2 No.1 (2013)

Nugraha, Erik (2016). Faktor-Faktor yang Mempengaruhi Manajemen Laba dan Dampaknya Terhadap Koefisien Respon Laba. SIKAP, Vol. 1, No. 1, pp. 9-21.

Nur, Emrinaldi (2012). Agency Theory and Corporate Governance, Laporan Keuangan-Media Pertanggungjawabaan yang Disalahgunakan Persfektif Manajemen Laba. PUSBANGDIK, Universitas Riau.

Nuswandari, Cahyani. (2013). Determinan Struktur Modal Dalam Perspektif Pecking Order Theory dan Agency Theory. Dinamika Akuntansi, Keuangan dan Perbankan, Vol. 2, No. 1, pp. 92-102.

Paramita dan Ratna. (2012). Pengaruh Leverage, Firm Size dan Voluntary Disclosure Terhadap Earnings Response Coefficient (ERC). Jurnal WIGA. 2. (2). pp. 103-118.

Pudjiastuti dan Mardiyah. (2006). The Influence of Manajemen laba on Earnings Quality. Simposium Nasional Akuntansi IX di Padang.

Rifani, Aulia (2013). Pengaruh Good Corporatte Governance Terhadap Hubungan Manajemen Laba Dan Kualitas Labaa(Studi Empiris Pada Perusahaan Go Public yang Terdaftar di CGPI). Program Studi Akuntansi, Fakultas Ekonomi-Universitas Negeri Padang.

Rilo dan Laksito (2017). Pengaruh Karakteristik Komite Audit terhadap Kualitas Laba. Diponegoro Journal of Accounting Vol. 6, No. 4, pp. 1-11.

Rona et al. (2015). Pengaruh Good Corporate Governance Terhadap Kualitas Laba Dengan Manajemen Laba sebagai Variabel Intervening. Jurnal SOROT, Vol. 10, No. 1, pp. 1 142.

Saleh et al. (2007). Audit Committee Characteristics and Earnings Management: Evidence From Malaysia. Asian Review of Accounting, 15(2), 147-163.

Sari dan Putri. (2014). Pengaruh Mekanisme Corporate Governance pada Manajemen Laba. EJurnal Akuntansi Universitas Udayana 8.1, pp. 94-104.

Scott, William R. (2009). Financial Accounting Theory, 5th Ed. Canada: Prentice-Hall.

Schipper, K dan Linda V. (2003). Earnings Quality. Accounting Horizon Vol. 17, Supplement, pp. 97-110.

Sulistyanto, Sri H (2008). Manajemen Laba : Teori dan Model Empiris. Jakarta: Grasindo.

Sugiyono. (2007). Metode Penelitian Administrasi. Bandung : Alfabeta

Taruno. (2013). Pengaruh Corporate Governance terhadap Kualitas Laba: Manajemen Laba sebagai Variabel Intervening. Accounting Analysis Journal 2 (3). 
Ujiyantho dan Pramuka. (2007). Mekanisme Corporate Governance, Manajemen Laba dan Kiinerja Keuangan. Prosiding, Simposium Nasional Akuntansi X, Makassar.

Wahyuni dan Muslim (2010). Pengaruh Earnings Management Terhadap Earnings Quality. Jurnal Kajian Akuntansi dan Auditing Vol.5, No. 2.

Widjaja dan Rovila (2011). AnalisissPerbedaan Kualitas Laba dan Nilai Perusahaan Sebelum dan Sesudah Adannya Komite pada Bank-bank Go Public di Indonesia. The Indonesian Accounting Review. Vol. 1 (2), pp. 117-134.

Yang et al. (2009). The Effect of Board Structure and Institutional Ownership Structure on Earnings Management. International Journal of Economics and Management, 3(2), 332353. 